\title{
Genetic Diversity in Prunus spinosa L. and Challenges in the Use of Autochthonous Sources
}

\section{Klaus EIMERT}

Geisenheim University, Center of Applied Biology, Institute of Botany, Germany

\section{Article Info:}

Research article

Corresponding author: Klaus EIMERT, e-mail:klaus.eimert@hs-gm.de

doi: http://dx.doi.org/10.17474/acuofd.05189

\section{ABSTRACT}

Genetic diversity in natural stands of autochthonous blackthorn (Prunus spinosa L.) of different German provenances has been analyzed using a highly reproducible high-annealing-temperature random amplified polymorphic DNA (HAT-RAPD) protocol. The findings were compared to those from seedstocks of the same provenances, reported earlier. Generally, genetic diversity in the natural stands was even lower (Ho 0.099-0.116) compared to the corresponding seedstocks (Ho 0.118-0.133). Furthermore, genetic differentiation was found to be moderate between natural residential sources (pairwise Fst 0.138-0.184, $22.527 \%$ variation among populations), but higher than between the seedstocks (pairwise Fst 0.086-0.104, $7.782 \%$ variation among populations). The findings are discussed in respect to German conservation law and its practical implementation.

Key words: Prunus spinosa; autochthonous; RAPD; genetic diversity; differentiation

\section{Prunus Spinosa L.'nin Genetik Çeşitliliği ve Yerli Popülasyon Kaynaklarının Kullanımındaki Zorluklar}

\section{ÖZET}

Almanya'nın farklı bölgelerindeki çakal eriği (Prunus spinosa L.) doğal türünün genetik çeşitliliği, yüksek yapışma sıcaklığında rastgele çoğaltılmış polimorfik DNA (HAT-RAPD) protokolü kullanılarak analiz edilmiştir. Bulgular daha önceki çalışmalarda kaydedilen benzer bölgelerden toplanmış tohum stoklarından elde edilen örneklerin bulgularıyla karşılaştırılmıştır. Genellikle doğal türlerdeki (suş) genetik çeşitlilik önceki çalışmalarda ölçülen değerden (Ho: 0,118-0,113) düşük olduğu (Ho; 0,099-0,116) belirlenmiştir. Dahası genetik farklılaşma doğal türlerde orta düzeyde (Fst; 0,138- 0,184; populasyonlar arası varyasyon oranı \% 22,527) ama tohum stoklarından elde edilen örneklerin değerlerinden (Fst; 0,0860,104; populasyonlar arası varyasyon oranı \% 7,782) daha yüksek olduğu belirlenmiştir. Bulgular Almanya koruma kanunları ve uygulamaları bakımından tartışılmıştır.

\section{INTRODUCTION}

Genetic diversity is generally agreed to be a main prerequisite for evolution providing raw material for selection (Rees et al. 2001, Crawford and Whitney 2010). Also natural genetic diversity provides raw material for breeding food and feed varieties (Hoisington et al. 1999, Esquinas-Alcázar
2005). While artificially increasing genetic diversity by mutation breeding or artificial crosses across breeding borders can increase genetic diversity, naturally occurring genetic diversity remains the largest pool of genes/allels to ensure healthy environments and secured food situation even during challenges like socioecological development and global climate 
change. Thus, conservation of genetic diversity (by protection of environment) was agreed upon as a common goal for humanity (Convention on biological diversity 1992). Those ageements have to be implementet into national law by the subscribing contries. In Germany, the Federal Conservation Act was accordingly amended in 2010 (BnatSchG) to (among other points) include conservation of genetic diversity. Thus, it also regulates the introduction of non-resident species into the open landscape (outside settled areas and not used in agri-, horti-, or silviculture) - which will be prohibited from 2020 on. Until then there is a period of transition during which use of residential sources for any species is required whenever possible. In the BnatschG, the term species is defined including sub-species levels like subspecies or even populations (BnatSchG 2010, \$7(2)3). This regulation presents a practical problem for the use of plants in open landscape plantation. While an increasing number of publications are available for forest trees (Kremer et al. 2002, Petit et al. 2003, Magri et al. 2006) not much is known about genetic constitution of many other plants including shrubs, widely used in open landscape plantings. Despite this lack of knopwledge, 9 regions of origin were introduced for woody plants (shrubs), not regulated by forrestry or agricultural laws in 2003 (BMVEL 2003). Base for those regions were ecological basic units based on geographical classification of natural landscapes in Germany according to Schmidt and Krause (1997). This regulation does not take into account finer ecological structuring nor does it consider the different biologies of plants species. In 2012 the number of regions of origin was further reduced to 6 (BMU 2012).

Faced with this situation we aimed to broaden our knowledge on one of the species most commenly used for plantings in the open landscape - blackthorn (Prunus spinosa L.).

Prunus spinosa L. (common blackthorn, sloe) is an insect-pollinated, animaldispersed shrub native to Europe, North Africa, and West Asia (Schütt et al. 1992). It is very wide-spread over Germany and most of Europe, and therefore it is often used in open landscape plantation and renaturation measures in Germany. Blackthorn is assumed to be allo-tetraploid $(2 n=4 x=32$, Reynders-Aloisi and Grellet 1994) and it also propagates strongly by root suckers (Guitian et al. 1993).

In the recent years, several publications emerged dealing with the genetic structure of blackthorn. Mohanty et al. (2000, 2002) analyzed cp-DNA to observe large scale genetic structure in Europe, including a few scattered samples from Germany. Isozyme analyses for several areas in Germany showed moderate to low nuclear genetic diversity within and among blackthorn populations (Leinemann et al. 2002, Fronia 2009). Eimert et al. (2012) also reported relatively low genetic diversity in and no to weak differentiation among residential seedstock sources of blackthorn. Similar levels of genetic diversity were detected in eight autochthonous blackthorne populations from Flanders using AFLP and morphometry (Mijnsbrugge et al. 2013). Interestingly, in those populations, higher differentiation of nuclear DNA was reported, although no obviuos morphometric differention was observed. Very recently, Leinemann et al. (2014) analyzed nuclear and chloroplast DNA of blackthorn from 17 natural populations from across three of the proposed regions of origin and of an Italian and a Hungarian population. Here also, moderate nuclear genetic diversity was observed within the populations and the differentiation between them was similar to that observed by Mijndbrugge et al. (2013) 
but higher than that found in seedstocks (Eimert et al. 2012). While Eimert et al. (2012) and Leinemann et al. (2014) analyzed genetic diversity in autochthonous seedstocks and natural populations of blackthorn in Germany, respectivelly, no direct comparison is available between the two sources. Therefore, in this paper, we analyzed the nuclear genetic diversity in natural stands of blackthorn that served as sources for seedstocks studied earlier (Eimert et al. 2012) and compared the two sets.

\section{MATERIAL and METHODS}

\section{Plant material}

Fully expanded leaves were collected from 40 individuals of each of the source populations which provided the seedstocks analyzed earlier (Eimert et al. 2012). That may or may not include the actual shrubs from which those seeds were collected, as those were not labeled at that time. Populations sampled (Figure 1) were located in (at that time) two regions of origin (BMVL 2003). Populations "Hö" (near the town of Höxter in the State of North Rhine- Westphalia) and "Fu" (near the town of Fulda in the State of Hessia) belong to the designated region of origin 4, while population " $\mathrm{Rh}$ " (in the Rheingau Region of the State of Hessia ) was located in the then region of origin 6 . For samples from population sampled in wild stands "WT" is added to the label. For the corresponding seedstocks, samples of the corresponding regions of origin from earlier studies (Eimert et al. 2012) were reanalyzed. Those poluplation are additionally labelled "Nu" (nursery material) and "ud." in case undifferentiated material was used.

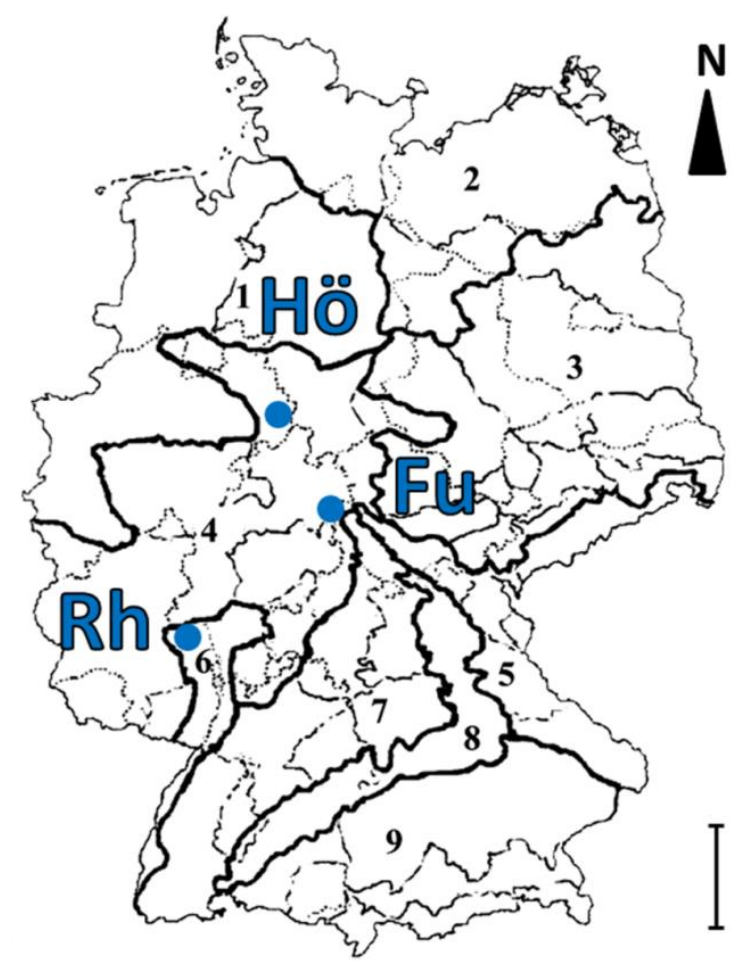

Figure 1 Schematic geographical map of Germany showing the sources of autochthonous plant material used in the recent analysis. Populations: Hö (Höxter), Fu (Fulda), Rh (Rheingau); Numbers refer to the designated regions of origin (BMELV 2003); bar $100 \mathrm{~km}$ 


\section{HAT-RAPD}

Total DNA was extracted from frozen leaves according to Eimert et al. (2012). A highly reproducible HAT-RAPD protocol was used to anylyze the DNAs of the freshly sampled natural population and to re-analyze the DNAs of the seedstocks used before with UBC primers 034, 060, 065, 096, 302, 319, 391, 727, 729, 746 and 766 under the same conditions (Eimert et al. 2012). PCR reactions were repeated at least twice to ensure reproducibility of the bands obtained.

\section{Data analysis}

BioNumerics software package (version 6.6.7; Applied Maths BVBA, Sint-MartensLatem, Belgium) was used for band scroring and matching, individual cluster analyses (unweighted pair-group method with arithmetical averages - UPGMA and neighbor-joining method - NJ) and principal coordinate analysis (PCoA) and the resulting character table was exported and used for population analyses (raw data available upon request). Neutrality of the used markers was tested with Fst outlier methods implemented in LOSITAN (Antao et al. 2008) and Tajima's D pairwise distance method implemented in Arlequin (Excoffier et al. 2005) using 1000 simulations. FAMD (Schlüter and Harris 2006) was used to compile descriptive statistics and to compute genetic distances for pairwise Fst values used in AMOVA and PCoA. Mantel test was conducted using the Isolation By Distance Web Service (Jensen et al. 2005). Genetic structure within and among the sampled populations was also analyzed using a Bayesian approach implemented in the software Structure (Pritchard et al. 2000). Geographic distances beween populations were estimated using the Google EarthTM (Google 2009) "ruler" tool.

\section{RESULTS}

\section{Population statistics}

All 360 Individuals of the different sources were analysed by HAT-RAPD using 11 primers resulting in 390 scorable band classes. While a high number of those bands were polymorphic, the gene diversity within the populations remained rather low (Table 1). Fixed bands and private bands could be observed in every poulation. However, no fixed private bands could be identified.

Table 1: Poulation statistics

\begin{tabular}{|c|c|c|c|c|c|c|}
\hline $\begin{array}{l}\text { population (region of } \\
\text { origin, source) }\end{array}$ & sample size & $\begin{array}{l}\text { \% poly- } \\
\text { morphic } \\
\text { bands }\end{array}$ & fixed bands $s_{1}$ & $\begin{array}{l}\text { private } \\
\text { bands }_{2}\end{array}$ & $\begin{array}{l}\text { fixed private } \\
\text { bands } 3\end{array}$ & $\mathrm{~h}_{4}$ \\
\hline $\mathrm{Fu}(\# 4, \mathrm{Nu})$ & 40 & 65.90 & 10 & 1 & 0 & 0.1107 \\
\hline $\mathrm{Hö} \mathrm{( \#} \mathrm{4,} \mathrm{Nu)}$ & 40 & 58.21 & 9 & 3 & 0 & 0.1119 \\
\hline $\mathrm{Rh}(\#$ 6, Nu) & 40 & 59.23 & 8 & 2 & 0 & 0.1049 \\
\hline $\mathrm{Ba}(\# 7, \mathrm{Nu})$ & 40 & 72.82 & 4 & 2 & 0 & 0.1061 \\
\hline $\mathrm{BB}(\mathrm{ud} .5, \mathrm{Nu})$ & 40 & 68.72 & 7 & 3 & 0 & 0.1161 \\
\hline $\mathrm{Hu}$ (ud., $\mathrm{Nu}$ ) & 40 & 74.62 & 1 & 4 & 0 & 0.1216 \\
\hline $\mathrm{Fu}(\# 4, \mathrm{WT})$ & 39 & 52.82 & 9 & 2 & 0 & 0.0993 \\
\hline Hö (\# 4, WT) & 42 & 67.95 & 6 & 12 & 0 & 0.1163 \\
\hline $\mathrm{Rh}(\#$ 6, WT) & 39 & 51.79 & 7 & 2 & 0 & 0.0968 \\
\hline
\end{tabular}


Also, it can be seen, that heterozygosity in all three wild populations is even lower than in the corresponding seedstock populations.

Using a stepwise mutation model with a $99.5 \%$ confidence intervall most of the loci used as markers in this study seem to behave selectivelly neutral in the wild autochthonous populations. Nevertheless, several Fst outliers could be detected identifying possible candidates for balancing (7 loci) and for positive (12 loci) selection (Figure 2).

Tajima's test of selective neutrality revealed no significant deviations from a neutral model in any of the tested populations (Table 2).

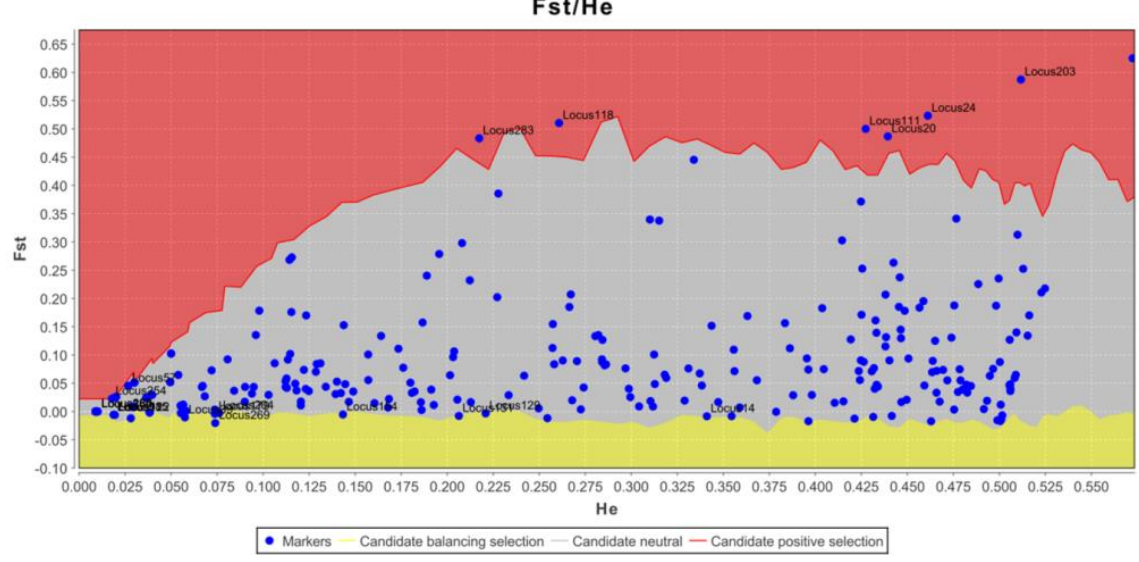

Figure 2 Fst outliers detected by LOSITAN in autochthonous wild populations (red area - candidates for positive selection, yellow area - candidates for balancing selection).

Table 2: Tajima's test of selective neutrality

\begin{tabular}{|l|l|l|l|l|l|l|l|l|l|}
\hline & $\begin{array}{l}\mathrm{Fu} \\
\mathbf{( N u}\end{array}$ & $\begin{array}{l}\mathrm{Hö} \\
(\mathbf{N u})\end{array}$ & $\begin{array}{l}\mathbf{R h} \\
\mathbf{( N u}\end{array}$ & $\begin{array}{l}\mathrm{Ba} \\
\mathbf{( N u})\end{array}$ & $\begin{array}{l}\mathrm{BB} \\
\mathbf{( N u )}\end{array}$ & $\begin{array}{l}\mathrm{Hu} \\
(\mathbf{N u})\end{array}$ & $\begin{array}{l}\text { Fu } \\
(\mathbf{W T})\end{array}$ & $\begin{array}{l}\text { Hö } \\
(\mathbf{W T})\end{array}$ & $\begin{array}{l}\mathbf{R h} \\
(\mathbf{W T})\end{array}$ \\
\hline Tajima's D & -0.129 & -0.039 & -0.105 & -0.396 & -0.159 & -0.188 & 0.075 & -0.065 & -0.081 \\
\hline P value & 0.531 & 0.555 & 0.545 & 0.400 & 0.515 & 0.479 & 0.583 & 0.527 & 0.525 \\
\hline
\end{tabular}

For Tajima's D, values $>2$ and $<-2$ are usually considered significant deviations from 0 .

\section{Genetic Structure - Distance based methods}

Clustering of all single individuals was conducted using UPGMA (Sokal and Micheneror 1958) and NJ (Saitou and Nei 1987) methods with either Jaccard (1901) or Dice (1945) coefficients. No significant differences in clustering were found with these different methods (data not shown).
While there are no larger clusters consisting uniformly of individuals of only one given population, one main clade consisted most of the individuals from sampled from the three wild stands, a second clade included most of the autochthonous seedstocks (except for $\mathrm{Ba}(\mathrm{Nu})$ ) and a third one which combined most of the commercial seedstocks and the Bavarian autochthonous seedstock (Figure 3). 


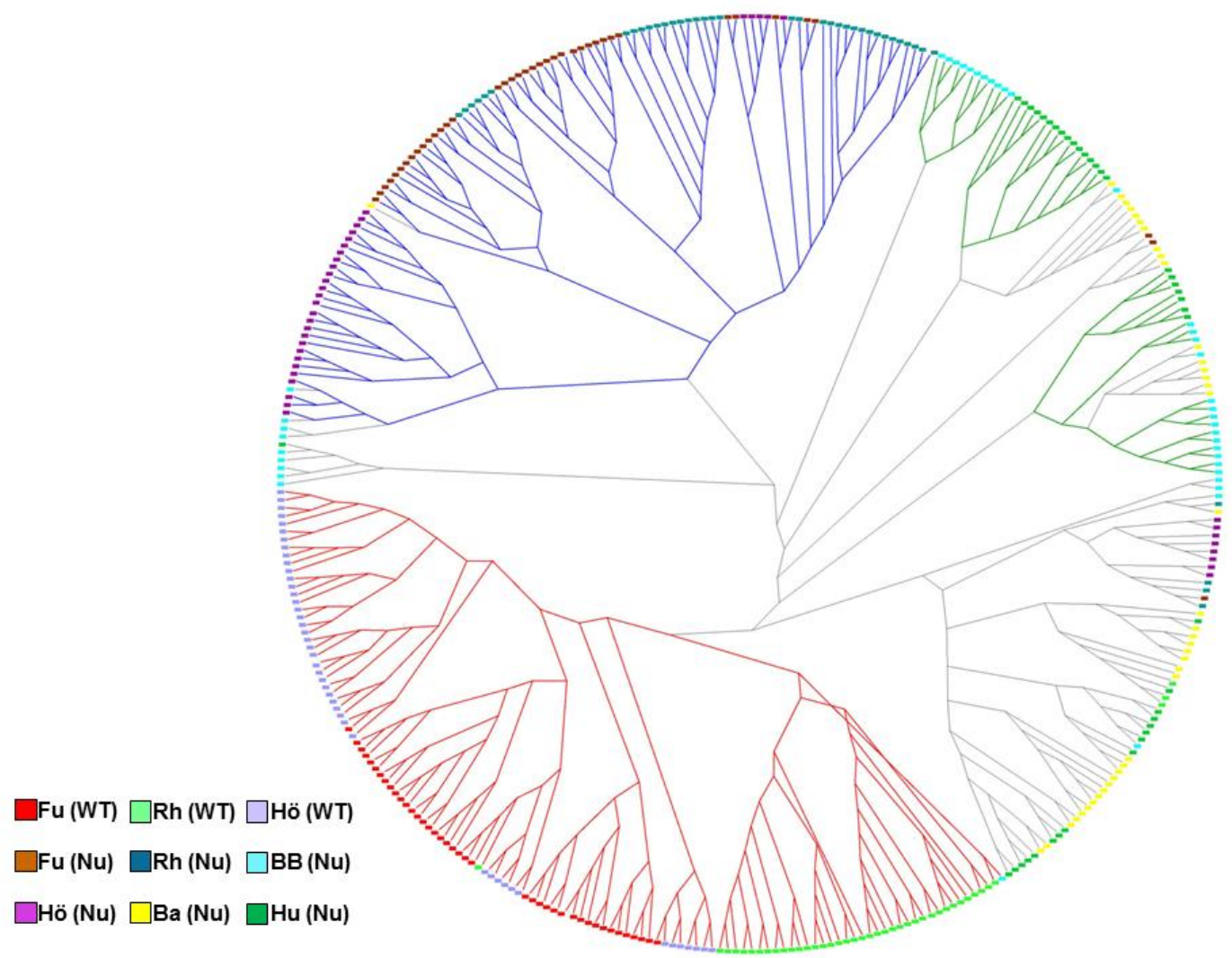

Figure 3 Radial cladogram showing the clustering of all screened individuals (neighbor joining, Jaccard).

The standard similarity was computed using Jaccard's similarity coefficient. Standard Jaccard distance transformation $(\mathrm{d}=1-\mathrm{s})$ was applied to calculate pairwise Fst values to access differentiation among populations (Table 3). Fst values were calculated for both neutral and non-neutral markers and no significant difference was observed (data not shown).

While the differentiation among the seedstock populations was usually weak there is mostly moderate to even strong differentiation between the wild populations and the seedstock populations and also among the wild populations themselves. Accordingly, the derived dendrogram apparently shows three larger clusters - a wider one consisting of all wild populations with the $\mathrm{Rh}(\mathrm{WT})$ population slightly removed and two tighter ones, one consisting of the autochthonous seedstocks (with the exception of $\mathrm{Ba}(\mathrm{Nu})$ ) and $\mathrm{a}$ another one consisting of the two undifferentiated commercial seedstocks and the Bavarian autochthonous seedstock (Figure 4). 
Table 3: Pairwise Fst values and geographic distances

\begin{tabular}{|c|c|c|c|c|c|c|c|c|c|}
\hline & $\begin{array}{l}\mathrm{Fu} \\
(\mathrm{Nu})\end{array}$ & $\begin{array}{l}\mathrm{Hö} \\
(\mathrm{Nu})\end{array}$ & $\begin{array}{l}\mathrm{Rh} \\
(\mathrm{Nu})\end{array}$ & $\begin{array}{l}\mathrm{Ba} \\
(\mathrm{Nu})\end{array}$ & $\begin{array}{l}\mathrm{BB} \\
(\mathrm{Nu})\end{array}$ & $\begin{array}{l}\mathrm{Hu} \\
(\mathrm{Nu})\end{array}$ & $\begin{array}{l}\mathrm{Fu} \\
(\mathrm{WT})\end{array}$ & $\begin{array}{l}\text { Hö } \\
\text { (WT) }\end{array}$ & $\begin{array}{l}\text { Rh } \\
\text { (WT) }\end{array}$ \\
\hline $\mathrm{Fu}(\mathrm{Nu})$ & --- & 133 & 137 & 155 & n.d. & $825^{\star}$ & & & \\
\hline $\begin{array}{l}\mathrm{Hö} \\
(\mathrm{Nu})\end{array}$ & 0.1039 & --- & 214 & 285 & n.d. & $927 \star$ & & & \\
\hline $\begin{array}{l}\mathrm{Rh} \\
(\mathrm{Nu})\end{array}$ & 0.0861 & 0.1158 & --- & 226 & n.d. & $900^{\star}$ & & & \\
\hline $\mathrm{Ba}(\mathrm{Nu})$ & 0.1194 & 0.1734 & 0.1146 & --- & n.d. & $685^{\star}$ & & & \\
\hline $\begin{array}{l}\mathrm{BB} \\
(\mathrm{Nu})\end{array}$ & 0.1003 & 0.1420 & 0.1132 & 0.0683 & --- & n.d. & & & \\
\hline $\begin{array}{l}\mathrm{Hu} \\
(\mathrm{Nu})\end{array}$ & 0.1181 & 0.1594 & 0.1250 & 0.0464 & 0.0530 & --- & & & \\
\hline $\begin{array}{l}\mathrm{Fu} \\
(\mathrm{WT})\end{array}$ & 0.2090 & 0.2719 & 0.2061 & 0.1547 & 0.1721 & 0.1642 & --- & & \\
\hline $\begin{array}{l}\text { Hö } \\
\text { (WT) }\end{array}$ & 0.1779 & 0.2232 & 0.1910 & 0.1469 & 0.1587 & 0.1411 & 0.1384 & --- & \\
\hline $\begin{array}{l}\mathrm{Rh} \\
\text { (WT) }\end{array}$ & 0.2288 & 0.2832 & 0.2406 & 0.1638 & 0.1879 & 0.1732 & 0.1841 & 0.1956 & --- \\
\hline
\end{tabular}

Above diagonal: pairwise geographical distances $(\mathrm{km})(\star$ estimate, n.d.-not determined); Below diagonal: Pairwise FST Values; values $<0.05=$ no, $0.05-0.14=$ weak, $0.15-0.24=$ moderate, $>0.25=$ strong genetic differentiation.

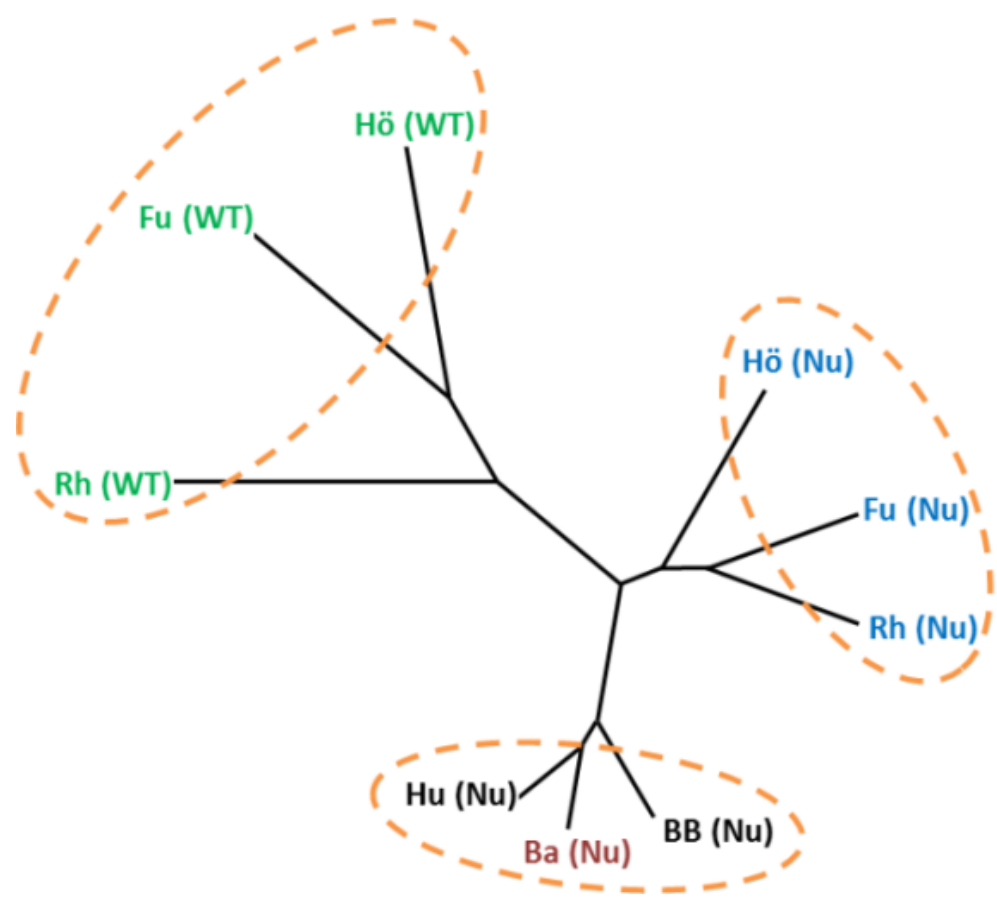

Figure 4 Dendrogram of the studied populations based on UPGMA analysis of pairwise distances using the Jaccard similarity index: Areas bordered by slashed lines indicate the three main clusters. 
Multivariate analysis ( $\mathrm{PCoA})$ reveals that the wild populations are most differentiated with the Rh (WT) beeing the most distant (Figure 5). The wild populations are losely grouped while the seedstock populations group tighter and the autochthonous seedstocks group together (except $\mathrm{Ba}(\mathrm{Nu})$ ) and even farther then the commercial ones.

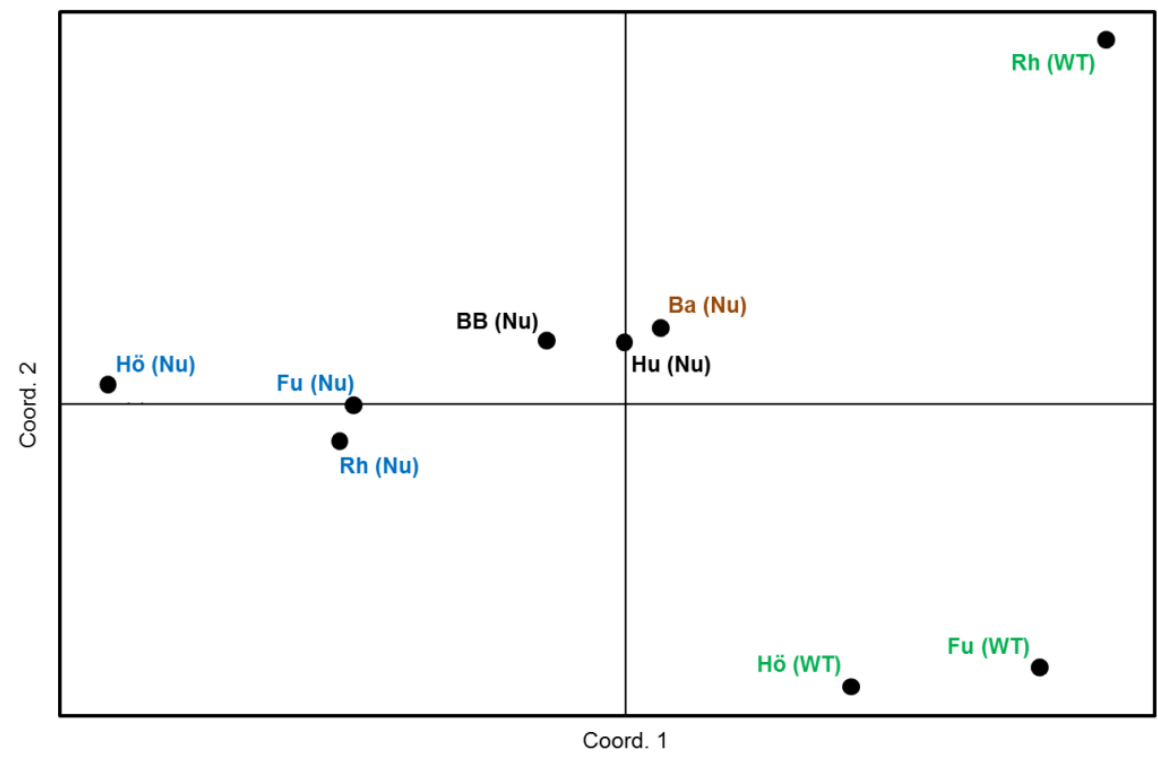

Figure 5 Multivariate (PCoA) analysis of seedstock and wild populations

An AMOVA revealed that, in all the seedstock populations the higher genetic diversity was mostly due to variation within the populations (92.218\%) and less among them $(7.782 \%)$. In the wild populations, the generally lower genetic diversity is shifted to $77.473 \%$ variation within and $22.527 \%$ among populations, respectively.

However, using Fisher's exact test for population differentiation (Raymond and Rousset 1995) no differentiation between any of the analyzed populations could be detected at the $95 \%$ significance intervall (after 30000 Markov transformations).
Testing for isolation by distance (Wright 1943) a Mantel Test showed no significant correlation between genetic and geographic distances in either seedstocks $(r=0.1770$, $\mathrm{p}=0.2200,999$ permutations) or the wild populations $(\mathrm{r}=0.0895, \mathrm{p}=0.2330,999$ permutations).

\section{Genetic Structure - Bayesian Estimates}

Possible genetic structures were also analyzed using the Bayesian approach based on the most likely $\mathrm{k}$ value (Evanno et al. 2005). Using the most sensitive settings a weak genetic structure $(\Delta \mathrm{K}=48.33)$ was shown with the most likely $\mathrm{k}=6$ (Figure 6 ). 


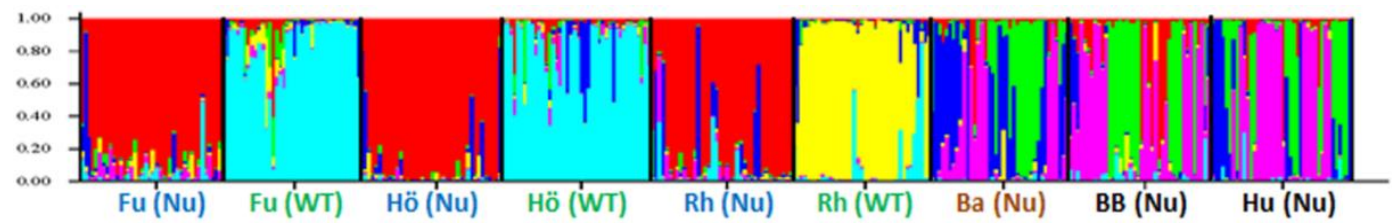

Figure 6 Bayesian clustering analysis of blackthorn populations for $\mathrm{K}=6$

For the highest probable $\mathrm{K}(=6)$ all autochthonous seedstock populations (except $\mathrm{Ba}(\mathrm{Nu})$ ) are located in one cluster. Of the wild populations, two $(\mathrm{Fu}(\mathrm{WT})$ and Hö(WT)) are grouped together while the third one $(\mathrm{Rh}(\mathrm{WT}))$ is farther removed and considered an extra cluster. Each of the commercial sources $(\mathrm{BB}(\mathrm{Nu})$ and
$\mathrm{Hu}(\mathrm{Nu})$ ) and the remaining autochthonous seedstock $(\mathrm{Ba}(\mathrm{Nu}))$ are much more divers and each constituted a separate cluster. When we remove those last three populations from analysis the Bayesian approach detects a further genetic structuring (Figure 7), though with a much lower $\Delta \mathrm{K}$ value (8.97).

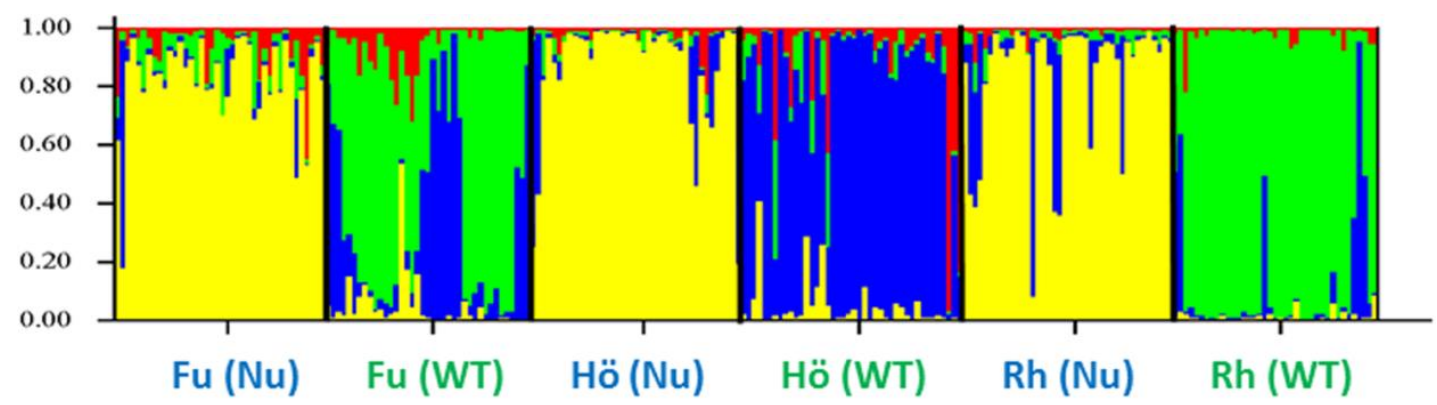

Figure 7 Bayesian clustering analysis of autochthonous sources of blackthorn with $\mathrm{K}=4$

With this weak structuring, all autochthonous seedstocks cluster together, while each autochthonous wild population is differentiated from them and from each other.

\section{DISCUSSION}

The above results on genetic differentiation between the tested autochthonous populations being about $22.5 \%$ of the total genetic variation are within the range reported by other authors in autochthonous blackthorn populations in Germany and bordering Flanders (Mijnsbrugge et al. 2013, Leinemann et al. 2014). In this, these results differ from the $7.8 \%$ observed earlier between the seedstocks populations harvested from exactly the same authochthounous wild populations (Eimert et al. 2012). Also, heterozygozity observed in the wild populations was lower than that of the corresponding seedstock populations. Thus, the situation observed in the wild autochthonous populations (lower genetic diversity and higher genetic differentiation) seems to follow the common assumption about genetic adaption of (isolated) populations to the local conditions. However, we submit that the picture is not that clearcut. If the differentiation we observed were due to adaptation, one would expect a deviation from HardyWeinberg equilibrium. Yet, no such obvious deviation could be detected Tajima's D shows now no significant deviation from a selective neutrality model, 
and only very few loci seemed to be under selective pressure as judged from the number of Fst outliers. Also, the fact that no fixed private bands could be detected in 390 markers seems to contradict an IBA (isolation by adaption) scenario. If, on the other hand, the differentiation was due to gene flow and drift assumed for the neutral theory of molecular evolution (Kimura 1968) one would expect an isolation by distance (IBD) effect for populations geographically and or ecologically seperated from each other. A Mantel test on that account did not confirm such effect. Furthermore, the amount of gene flow calculated from these weak Fst values is accordingly high with $\mathrm{Nm}=5.558(\mathrm{Nm}=$ $0.5(1$ - Fst $) / F s t)$ meaning that to explain this low differentiation between our aotuochthonous populations a migration of more than 5 individuals per generation into each population would be required. As the geographical distance between those populations is more than $130-210 \mathrm{~km}$ this seems an unlikely event. On the other hand, the measurement of gene flow cannot distinguish between recent or historical events (Lowe et al. 2008). Humans have apparently used blackthorn fruits for consumption since the neolithic (Karg and Markle 2002, Martin et al. 2008) and it was cultivated in Nothern Europe since the Roman Empire (Karnitsch 1953). Thus, anthropogenic distribution of blackthorn seems very plausible.

It also has been noted, that in many cases the impact of processes on genetic structuring can be obscured (Orsini et al. 2013). Thus, it can be difficult to distinguish the results of IBD and IBC (isolation by colonization). These authors propose to study the patterns of variation of both neutral and non-neutral markers in order to distinguish between the different driving forces of genetic differentiation. Using those parameters, we observe a pattern more akin to that described bei
Orsini et al. (2013) as typical for IBC rather than that for IBD or IBA (isolation by adaption) in that the Fst values for neiter the neutral nor the non-neutral loci vary significantly over geographical distance.

Summarizing, we observe a weak pattern of differentiation between wild autochthonous populations of blackthorn in Germany. No obvious deviation from neutral evolution was detected and, thus, isolation by distance or by adaption seems unlikely. The observed patterns support an (weak) isolation by colonialization probably further driven by landscape fragmentation.

On the other hand, the situation in seedstock populations collected from those wild stands is different. That the genetic diversity within those populations is higher is not surprizing by itself, considering the almost ubiquitous occurrence of blackthorne in Germany (although mostly in fragmented smaller stands), its outcrossing biology and tetraploidy. At the same time, the genetic differentiation between the seedstocks populations is smaller than that between their corresponding source populations. That leads to the situation that, genetically, the wild autochthonous populations are more similar to each other than to their own more heterozygous offspring (Fig.3).

This situation presents some problems for conservation measures. If the main function of the Conservation Law is to maintain the genetic status quo of an existing population/sub-population the usage of residential seedstocks will not necessarily accomplish that goal in full. If the weak differentiation we observed in wild autochthonous blackthorn populations is indeed mainly due to colonization even the use of autochthonous seedstock will not maintain the same narrow genetic composition. That will 
obviously depend on the concerned species, its current genetic composition and its reproductive biology. Thus, from a biological point of view an accordingly adapted approach for each species would be appropriate.

For blackthorn it seems that, at least for the regions of origin 4 and 6 , the observed genetic situation does not correspond with the proposed geographic differentiation, as has been shown for other regions (Leinemann et al. 2014). A more thorough analysis of populations from all regions of Germany would be required to propose corresponding and biologically meaningful regions of origin. A recently implemented further reduction of the proposed number of regions of origin for autochthonous plants from 9 to 6 (BMU 2012) might be nearer to the "genetic truth" for blackthorn. Nonetheless, the situation will have to be evaluated for each species separately.

\section{ACKNOWLEDGEMENTS}

This work has in part been developed through funding from Hochschule RheinMain University of Applied Sciences Wiesbaden Rüsselsheim Geisenheim (grant FHW-Nr. 40130130). We are grateful to Mrs. Hüwe for excellent technical support.

\section{REFERENCES}

Antao T, Lopes A, Lopes RJ, Beja-Pereira A, Luikart, G (2008) LOSITAN: a workbench to detect molecular adaptation based on a Fst-outlier method. BMC Bioinformatics 9: 323

BMU (Bundesministerium für Umwelt, Naturschutz und Reaktorsicherheit) (2012) Leitfaden zur Verwendung gebietseigener Gehölze. Selbstverlag, Berlin

BMVEL (Bundesministerium für Verbraucherschutz, Ernährung und Landwirtschaft) (2003) Verwendung einheimischer Gehölze regionaler Herkunft für die freie Landschaft. Ein Beitrag zur Erhaltung und Förderung der biologischen Vielfalt. Selbstverlag, Bonn
BnatSchG (Gesetz über Naturschutz und Landschaftspflege) (2010) Bundesnaturschutzgesetz vom 29.07.2009, in Kraft getreten am 01.03.2010. BGB1 I:2542

Convention on biological diversity (1992) Secretariat of the convention on biological diversity. http://www.cbd.int/programmes/outreach/aware ness/publications.shtml. Accessed 18th August 2011

Crawford KM, Whitney KD (2010) Population genetic diversity influences colonization success. Mol Ecol 19(6):1253-1263

Dice LR (1945) Measures of the amount of ecologic association between species. Ecology 26: 297-302

Eimert K, Rückert F-E, Schröder M.B. (2011) Genetic diversity within and between seedstock populations of several German autochthonous provenances and conventionally propagated nursery material of blackthorn (Prunus spinosa L.). Plant Syst Evol 298(3):609-618

Esquinas-Alcázar J (2005) Science and society: protecting crop genetic diversity for food security: political, ethical and technical challenges. Nat Rev Genet 6(12):946-953

Evanno G, Regnaut S, Goudet J (2005) Detecting the number of clusters of individuals using the software STRUCTURE: a simulation study. Mol Ecol 14(8):2611-2620

Excoffier L, Laval G, Schneider S (2005) Arlequin (version 3.0): an integrated software package for population genetics data analysis. Evolutionary Bioinformatics Online 1:47-50

Fronia R (2009) Prüfung der Identität und Variabilität gebeietsheimischer und gebietsfremder Herkünfte von Prunus spinosa L. und Cornus sanguinea L. zur Verwendung in der freien Landschaft. Der Andere Verlag, Tönning, Lübeck, Marburg

Google (2014) Google Earth. Available: http://www.google.com/earth

Guitián J, Guitián P, Sánchez JM (1993) Reproductive biology of two Prunus species (Rosaceae) in the Northwest Iberian Peninsula. Plant Syst Evol 185(3-4):153-165

Jensen JL, Bohonak AJ, Kelley ST (2005) Isolation by distance, web service. BMC Genet 6(1):13

Leinemann L, Bendixen K, Kownatzki D, Hattemer HH, Liepe K, Stenger G (2002) Genetische Untersuchungen an Landschaftsgehölzen im Hinblick auf die Erzeugung und Zertifizierung von Vermehrungsgut. Allgemeine Forst- und Jagdzeitung 173:146-152

Leinemann L, Kleinschmit J, Fussi B, Hosius B, Kuchma O, Arenhövel W, Finkeldey R (2014) Genetic composition and differentiation of sloe (Prunus spinosa L.) populations in Germany with respect to the tracing of reproductive plant 
material. Plant Syst Evol. doi:10.1007/s00606014-1027-7

Vander Mijnsbrugge K (2013) Genetic and morphological variability among autochthonous Prunus spinosa populations in Flanders (northern part of Belgium): implications for seed sourcing. Plant Ecol Evol 146(2):193-202

Mohanty A, Martín JP, Aguinagalde I (2000) Chloroplast DNA diversity within and among populations of the allotetraploid Prunus spinosa L. Theor Appl Genet 100(8):1304-1310

Mohanty A, Martín JP, Aguinagalde I (2002) Population genetic analysis of European Prunus spinosa (Rosaceae) using chloroplast DNA markers. Am J Bot 89(8):1223-1228

Reynders-Aloisi S, Grellet F (1994) Characterization of the ribosomal DNA units in two related Prunus species (P. Cerasifera and P. Spinosa). Plant Cell Rep 13(11):641-646

Hoisington D, Khairallah M, Reeves T, Ribaut J-M, Skovmand B, Taba S, Warburton M (1999) Plant genetic resources: What can they contribute toward increased crop productivity? P Natl Acad Sci USA 96(11):5937-5943

Jaccard P (1901) Distribution de la flore alpine dans le bassin des Dranses et dans quelques régions voisines. Bull Soc Vaud Sci Nat 37:241-272

Karg S, Markle T (2002) Continuity and changes in plant resources during the Neolithic period in western Switzerland. Veg Hist Archaeobot 11:169-176

Karnitsch P (1953) Fundberichte im Jahrbuch der Stadt Linz 1951. Pro Austria Romana 3:26

Kimura, M (1968) Evolutionary rate at the molecular level. Nature 217(5129):624-626

Kremer A, Kleinschmit J, Cottrell J, Cundall EP, Deans JD, Ducousso A, Stephan BR (2002) Is there a correlation between chloroplastic and nuclear divergence, or what are the roles of history and selection on genetic diversity in European oaks? Forest Ecol Manag 156(1-3):7587

Lowe A, Harris S, Ashton P (2008) Ecological genetics: design, analysis, and application. Blackwell, Malden

Magri D. Vendramin GG, Comps B, Dupanloup I, Geburek T, Gömöry D, de Beaulieu J-L (2006) A new scenario for the quaternary history of
European beech populations: palaeobotanical evidence and genetic consequences. The New Phytologist, 171(1), 199-221

Martin L, Jacomet S, Thiebault S (2008) Plant economy during the Neolithic in a mountain context: the case of "Le Chenet des Pierres" in the French Alps (Bozel-Savoie, France). Veg Hist Archaeobot 17:113-122

Nei M (1978) Estimation of average heterozygosity and genetic distance from a small number of individuals. Genetics 89(3):583-590.

Orsini L, Vanoverbeke J, Swillen I, Mergeay J, De Meester L (2013) Drivers of population genetic differentiation in the wild: isolation by dispersal limitation, isolation by adaptation and isolation by colonization. Mol Ecol 22(24):5983-5999

Petit RJ, Aguinagalde I, de Beaulieu J-L, Bittkau C, Brewer S, Cheddadi R, Vendramin GG (2003) Glacial refugia: hotspots but not melting pots of genetic diversity. Science 300(5625):1563-1565

Pritchard JK, Stephens M, Donnelly P (2000) Inference of population structure using multilocus genotype data. Genetics 155 (2):945959.

Raymond M, Rousset F (1995) An exact test for population differentiation. Evolution 49(6):1280

Rees M, Condit R, Crawley M, Pacala S, Tilman D (2001) Long-term studies of vegetation dynamics. Science 293(5530):650-655

Saitou N, Nei M (1987) The neighbor-joining method: a new method for reconstructing phylogenetic trees. Mol Biol Evol 4(4):406-425.

Schlüter PM, Harris SA (2006) Analysis of multilocus fingerprinting data sets containing missing data. Mol Ecol Notes 6(2):569-572

Schmidt PA, Krause A (1997) Zur Abgrenzung von Herkunftsgebieten bei Baumschulgehölzen für die freie Landschaft. Natur und Landschaft 72:92-95

Schütt P, Schuck HJ, Stimm B (eds) (1992) Lexikon der Forstbotanik. Verlag Hüthig, Jehle Rehm, Heidelberg

Sokal R and Michener C (1958) A statistical method for evaluating systematic relationships". University of Kansas Science Bulletin 38: 1409_ 1438

Wright S (1943) Isolation by Distance. Genetics 28(2):114-138 